\title{
Project "Eat well, live healthy": preparation of three menus to ensure good nutritional support for special disease conditions
}

\author{
Projeto "Comer bem, Viver com saúde": elaboração de três menus que proporcionem um bom \\ aporte nutricional em doenças especiais
}

\author{
Beatriz Venda, Nelson Tavares \\ CBIOS, Escola de Ciências e Tecnologias da Saúde, Universidade Lusófona, Campo Grande 376,1649-024 Lisboa \\ PORTUGAL \\ Email: nelson.tavares@ulusofona.pt
}

\begin{abstract}
Nutrition is an important component in the treatment of disease. A correct and balanced food intake before, during, and after treatment can help the patient feel better, maintain weight and nutrient reserves, decrease the risk of infection, increase tolerance to treatment, effect and consequently contribute for better and faster recovery. Oncologic disease (whose incidence rate of new cases of malignant tumors has been increasing regularly, with an increase of 4\% of cases in Portugal registered between 2009 and 2010) has repercussions as a harmful experience for well-being and quality of life, not only as a result of the disease itself, but also the treatment. It is in this context that the project "Eat well, live healthy" emerges, whose overall objective aims to provide patients access to a varied menu, balanced and rich from a nutritional point of view. With menus (starter, soup, main course and dessert) that promote food intake and ensure good nutritional value, we want patients to know that an adjusted food intake allows them to achieve the energy and protein requirements; reduce and mitigate the side effects of treatment and allow a better recovery, a reduction of hospitalization time and an improved quality of life.
\end{abstract}

Keywords: cancer; treatment; symptoms; nutritional requirements.

\begin{abstract}
Resumo
A Nutrição é uma componente importante no tratamento das doenças mais graves. Uma correta e equilibrada ingestão alimentar antes, durante e após o tratamento pode contribuir para que o doente se sinta melhor, mantenha o seu peso e reservas de nutrientes, diminua o risco de infeção, seja mais tolerante ao tratamento, aos seus efeitos e consequentemente contribua para uma melhor e mais rápida recuperação. A doença oncológica (cuja taxa de incidência de novos casos de tumores malignos tem vindo a aumentar regularmente) registando-se entre 2009 e 2010 um aumento de 4\% dos casos em Portugal, repercute-se como uma experiência lesiva para o bem-estar e qualidade de vida, não só como consequência da doença em si, como também do tratamento relacionado.

E neste contexto que surge o projeto "Comer bem, Viver com saúde", cujo objetivo geral visa proporcionar ao doente o acesso a um menu variado, equilibrado e rico do ponto de vista nutricional. Com menus (entrada, sopa, prato principal e sobremesa) que promovam a ingestão alimentar e garantam um bom aporte nutricional, pretendemos que os doentes se consciencializem de que uma alimentação ajustada lhes permite suprimir as necessidades energéticas e proteicas, reduzir e suavizar os efeitos colaterais resultantes do tratamento assim como permitir uma melhor recuperação, reduzir o tempo de hospitalização e uma melhor qualidade de vida.
\end{abstract}

Palavras - Chave: cancro; tratamento; sintomas; necessidades nutricionais. 


\section{Introduction}

Cancer is among the leading causes of morbidity and mortality throughout the world, and it is expected that the number of new cases will increase significantly in the next decades ${ }^{1,2,3,4}$. In Portugal, the incidence rate of new cases of malignant tumors has increased regularly, recording between 2009 and 2010 a 4\% increase of cases ${ }^{1}$. The oncological disease echoes as a damaging experience for the well-being and quality of life, not only as a result of the disease itself, but also from the treatment to which the patient is submitted. Patients with cancer are at risk of malnutrition, not only because of the physical and metabolic effects of pathology but also due to the effects of the treatments. Inadequate nutritional intake, loss of muscle mass and the activation of the systemic inflammation syndrome can result from catabolic changes that occur in cancer patients. The causes that lead to inadequate intake are complex and multifactorial. Reduced intake of food is caused by primary anorexia and can be aggravated by the existence of secondary events that affect oral ingestion, such as: oral ulceration, xerostomia, problems with the teeth, bowel obstruction, malabsorption, constipation, diarrhea, nausea, vomiting, decreased intestinal motility, chemo-sensory changes and side effects of medication $^{2,4,5}$. The loss of muscle protein is a consequence of cachexia associated with cancer that affects serious and severe physical function and patient tolerance to the treatment. Studies report that the loss of skeletal muscle mass with or without fat loss is the main aspect of malnutrition associated with cancer and is responsible for an increased risk of occurrence of post-operative complications, chemotherapy-related toxicity and mortality ${ }^{2,4}$.

The systemic inflammation syndrome in cancer patients has a great impact and influence on the levels of protein, carbohydrate, and lipid metabolism. In protein metabolism it is associated with changes in the protein turnover, the consequent loss of muscle mass and increasing the production of acute phase proteins. In the metabolism of carbohydrates, it is associated with insulin resistance and a decrease in the glucose tolerance. Finally, in lipid metabolism, it impacts on the capacity of lipid oxidation, which can be maintained or increased in patients with cancer, especially with weight loss. It should be noted that metabolic disorders such as obesity and insulin resistance are associated with an increased risk of recurrence of cancer ${ }^{4}$.

Nutritional interventions should be targeted giving special importance to the maintenance and increase of muscle mass, as well as to ensure the necessary energy levels. It is in this context that the project "Eat well,

\section{Introdução}

O cancro está entre as principais causas de morbilidade e mortalidade em todo o mundo, e espera-se que o número de novos casos aumente significativamente nas próximas décadas ${ }^{1,2,3,4}$. Em Portugal, a taxa de incidência de novos casos de tumores malignos tem vindo a aumentar regularmente, tendo-se registado entre 2009 e 2010 um aumento de $4 \%$ dos $\operatorname{casos}^{1}$. A doença oncológica repercute-se como uma experiência lesiva para o bem-estar e qualidade de vida, não só como consequência da doença em si, como também do tratamento a que o doente oncológico é sujeito.

Os pacientes com cancro estão em risco de desnutrição, não só devido aos efeitos físicos e metabólicos da patologia como também devido aos efeitos resultantes dos tratamentos. A inadequada ingestão nutricional, a perda de massa muscular e a ativação do síndrome de inflamação sistémico resultam das alterações catabólicas que ocorrem em pacientes oncológicos. As causas que conduzem a uma ingestão insuficiente são complexas e multifatoriais. A ingestão reduzida de alimentos é causada por anorexia primária e pode ser agravada pela existência de acontecimentos secundários que afetam a ingestão oral, como: ulceração oral, xerostomia, problemas com a dentição, obstrução intestinal, má absorção, obstipação, diarreia, náuseas, vómitos, reduzida motilidade intestinal, alterações quimio-sensoriais e efeitos colaterais da medicação $0^{2,4,5}$.

A perda de proteína muscular é uma consequência da caquexia associada ao cancro que afeta de forma grave e severa a função física e a tolerância do doente ao tratamento. Estudos referem que a perda de massa muscular esquelética com ou sem perda de gordura, é o principal aspecto de malnutrição associada ao cancro e que é responsável por uma aumento do risco de ocorrência de complicações pós-operatórias, toxicidade associada à quimioterapia e mortalidade ${ }^{2,4}$.

O síndrome de inflamação sistémica em doentes oncológicos, tem um grande impacto e influência ao nível do metabolismo proteico, dos hidratos de carbono e lipídico. No metabolismo proteico está associado a alterações do turnover proteico, à consequente perda de massa muscular e ao aumento da produção de proteínas de fase aguda. No metabolismo de hidratos de carbono, está associado à resistência à insulina e a uma diminuição da tolerância à glicose. Por fim, no metabolismo lipídico, tem impacto na capacidade de oxidação lipídica, que pode ser mantida ou aumentada em pacientes com cancro, especialmente aquando a perda de peso. É de salientar ainda, que distúrbios metabólicos como a obesidade e situações de resistência à insulina estão associados a um aumento dos riscos de recorrência do cancro ${ }^{4}$. 
live healthy" aims to provide for the oncological patient three varied, balanced and nutrition rich menus that promote food intake and guarantee an adequate nutritional contribution.

\section{Material and Methods}

For the preparation of Menu 1, food and spices including nuts, milk, water, whole wheat flour, rye flour, yeast, salt, butter beans, onions, celery, tomato, salmon, squid, pepper, watercress, lettuce, eggs, garlic, coriander, parsley, olive oil, corn starch, brown sugar, raspberry, apple, yellow sugar and peanuts were used. In Menu 2, grain, coriander, olive oil, whole wheat flour, yeast, salt, water, watercress, sweet potatoes, onion, garlic, carrot, pumpkin, leek, elbow pasta, chicken, peppers, zucchini , peas, tomato, brown rice, noodles, half-fat milk, natural solid yogurt, cinnamon stick, yellow sugar and egg yolks were used. For Menu 3, tuna, egg, mayonnaise, whole wheat flour, water, yeast, salt, peas, onion, garlic, olive oil, sweet potatoes, grain, salmon, hake loins, bread grated, lemon jelly and natural yogurt were used. Three menus were developed, each consisting of starter, soup, main course, and dessert. For the preparation of the dishes included in the menus, only foods were used, not supplements. The dishes were prepared on the basis of the existing recommendations of The European Society for Clinical Nutrition and Metabolism (ESPEN) ${ }^{4}$ and the American Society for Parenteral and Enteral Nutrition (ASPEN) ${ }^{6}$ applied to oncology patients. After choosing the recommended values considered as most appropriate, the calculations of protein, lipids, carbohydrates and energy were made. The chosen distribution was $20 \%$ protein, $30 \%$ lipids and $50 \%$ carbohydrates. For quantifying macronutrients of each of the dishes the Food Composition table of INSA - the National Institute for Health Dr. Ricardo Jorge was used ${ }^{7}$. An average weight of $65 \mathrm{~kg}$ was stipulated and calculations were made of energy needs from protein, carbohydrates and lipids, taking into account also the values chosen as most suitable recommendations. These calculated values served as reference: Energy - $1950 \mathrm{kcal}$; Protein 97. 5 g; Lipids - 65.0 g; Carbohydrates - 243.75 g
As intervenções nutricionais devem ser orientadas dando especial importância à manutenção e aumento de massa muscular, assim como garantir que as necessidades energéticas sejam suprimidas. É neste contexto que surge o projeto "Comer bem, Viver com saúde" cujo objetivo geral visa disponibilizar para o doente oncológico três menus variados, equilibrados e ricos do ponto de vista nutricional, que promovam a ingestão alimentar e garantam um adequado aporte nutricional.

\section{Materiais e Métodos}

Para a execução do Menu 1 recorreu-se à utilização de alimentos e especiarias como: nozes, leite, água, farinha de trigo integral, farinha de centeio, fermento, sal, feijão-manteiga, cebola, aipo, caldo de galinha, louro, tomate, salmão, lula, pimento, agrião, alface, ovos, alho, coentros, salsa, azeite, amido de milho, açúcar mascavado, framboesa, maçã, açúcar amarelo e amendoins. Na elaboração do Menu 2: grão, coentros, azeite, farinha de trigo integral, fermento, sal, água, agrião, batata doce, cebola, alho, cenoura, abóbora, alho francês, caldo de galinha, massa-cotovelo, frango, pimentos, courgete, ervilhas, tomate, arroz integral, aletria, leite meio gordo, iogurte sólido natural, pau de canela, ácucar amarelo e gemas de ovo. No Menu 3 foram utilizados : atum, ovo, maionese, farinha trigo integral, água, fermento, sal, ervilhas, cebola, alho, azeite, batata doce, grão, salmão, lombos de pescada, pão ralado, gelatina de limão e iorgute natural.

Procedeu-se à elaboração de três menus, compostos cada um deles por entrada, sopa, prato principal e sobremesa. Para a confecção dos pratos contemplados nos menus recorreu-se, unicamente, à utilização de alimentos, não tendo sido utilizado qualquer tipo de suplemento alimentar. Os pratos foram elaborados com base nas recomendações existentes da The European Society for Clinical Nutrition and Metabolism (ESPEN) ${ }^{4}$ e da American Society for Parenteral and Enteral Nutrition (ASPEN) ${ }^{6}$ direcionadas para doentes oncológicos. Após escolhidos os valores das recomendações que foram considerados como mais adequados, procedeu-se ao cálculo das necessidades de proteína, lípidos, hidratos de carbono e energia. A distribuição seguida foi de $20 \%$ de proteína, $30 \%$ de lípidos e $50 \%$ de hidratos de carbono. Para a quantificação dos macronutrientes de cada um dos pratos foi utilizada a Tabela de Composição de Alimentos do INSA Instituto Nacional de Saúde Doutor Ricardo Jorge ${ }^{7}$. Foi estipulado um peso médio de $65 \mathrm{Kg}$ e a partir daí procedeu-se aos cálculos das necessidades energéticas, de proteína, hidratos de carbono e lípidos, tendo em conta, também os valores das 


\section{Results and Discussion}

In Menu 1 the starter was composed of walnut bread and apple jam with peanuts. The soup was prepared with beans, celery and tomato. For main course, salmon skewers, with squid and peppers, accompanied by a mixed salad (watercress, lettuce, onion, avocado and walnut) and an açorda of rye bread and whole wheat flour were chosen. Milk cream with raspberries was the dessert chosen to finish Menu 1. In Menu 2 the starter consisted of coriander hummus served with whole wheat bread. The soup chosen was watercress with elbow pasta and the main dish composed of chicken stewed with vegetables, accompanied by brown rice. The dessert of Menu 2 chosen was a vermicelli ice cream. In Menu 3 a starter of canapés of tuna served with toasts of integral bread was chosen. The soup prepared was a cream of pea with chopped egg. For main course was salmon hamburger made with pea puree. The dessert was a lemon mousse. After performing all the calculations for the prepared dishes it was found that through Menu $1,71 \%$ of the daily requirement of energy, $67 \%$ of proteins, $81 \%$ of lipids and $60 \%$ of carbohydrates could be satisfied. Through Menu 2, 72\% of the daily requirements of energy, $98 \%$ protein, $49 \%$ recomendações escolhidos como mais adequados. Estes valores calculados serviram como referência: Energia - $1950 \mathrm{Kcal}$; Proteína - 97,5 g; Lípidos - 65,0 g; Hidratos de Carbono - 243,75 g.

\section{Resultados e Discussão}

No Menu 1 a entrada foi composta por pão de noz e compota de maçã com amendoins. A sopa foi preparada com feijão, aipo e tomate. Para prato principal optou-se pela confeção de espetadas de salmão, com lulas e pimentos, acompanhados por uma salada mista (de agrião, alface, cebola, abacate e noz) e uma açorda de pão de centeio e farinha de trigo integral. Leite creme com framboesas foi a sobremesa escolhida para terminar o Menu 1. No Menu 2 a entrada foi constituída por húmus de coentros servido com pão integral. A sopa escolhida foi de agrião com massa cotovelinho e o prato principal composto por frango guisado com legumes, acompanhado por arroz integral. A sobremesa do Menu 2 foi um gelado de aletria. No Menu 3 a entrada optou-se por canapés de atum servidos com tostas de pão integral. A sopa preparada foi um creme de ervilhas com ovo picado. Para prato principal optou-se pela confec-

Table 1/ Tabela 1 - Comparison of the calculated reference values with the values obtained from the prepared dishes of Menu 1/ Quadro de comparação dos valores de referência calculados com os valores obtidos dos pratos confecionados do Menu 1.

\begin{tabular}{|l|l|l|l|l|}
\hline & $\begin{array}{l}\text { Valor } \\
\text { Energético/ } \\
\text { Energy } \\
\text { (Kcal) }\end{array}$ & $\begin{array}{l}\text { Proteína/ } \\
\text { Protein (g) }\end{array}$ & $\begin{array}{l}\text { Lipidos/Lipids } \\
\text { (g) }\end{array}$ & $\begin{array}{l}\text { Hidratos de } \\
\text { carbono/ } \\
\text { Carbohydrates } \\
\text { (g) }\end{array}$ \\
\hline $\begin{array}{l}\text { Valores de referência } \\
\text { calculados/Calculated } \\
\text { Reference Values }\end{array}$ & 1950,00 & 98,00 & 65,00 & 244,00 \\
\hline $\begin{array}{l}\text { Valores obtidos dos pratos } \\
\text { confecionados/Obtained } \\
\text { values from prepared dishes }\end{array}$ & 1380,00 & 65,00 & 53,00 & 145,00 \\
\hline
\end{tabular}


Table 2/ Tabela 2- Comparison of the calculated reference values with the values obtained from the prepared dishes of Menu 2/ Quadro de comparação dos valores de referência calculados com os valores obtidos dos pratos confecionados do Menu 2.

\begin{tabular}{|l|l|l|l|l|}
\hline & $\begin{array}{l}\text { Valor } \\
\text { energético/ } \\
\text { Energy (Kcal) }\end{array}$ & $\begin{array}{l}\text { Proteína/ } \\
\text { Protein }(\mathrm{g})\end{array}$ & $\begin{array}{l}\text { Lípidos/ Lipids } \\
(\mathrm{g})\end{array}$ & $\begin{array}{l}\text { Hidratos de } \\
\text { carbono/ } \\
\text { Carbohydrates } \\
(\mathrm{g})\end{array}$ \\
\hline $\begin{array}{l}\text { Valores de referência } \\
\text { calculados/ Calculated } \\
\text { Reference Values }\end{array}$ & 1959,00 & 98,00 & 65,00 & 244,00 \\
\hline $\begin{array}{l}\text { Valores obtidos dos pratos } \\
\text { confecionados/ Obtained } \\
\text { values from prepared dishes }\end{array}$ & 1405,61 & 95,15 & 32,11 & 182,20 \\
\hline
\end{tabular}

Table 3/Tabela 3- Comparison of the calculated reference values with the values obtained from the prepared dishes of Menu 3/ Quadro de comparação dos valores de referência calculados com os valores obtidos dos pratos confecionados do Menu 3.

\begin{tabular}{|l|l|l|l|l|}
\hline & $\begin{array}{l}\text { Valor } \\
\text { energético/En } \\
\text { ergy (Kcal) }\end{array}$ & Proteína/ Protein (g) & Lípidos/ Lipids (g) & $\begin{array}{l}\text { Hidratos de carbono/ } \\
\text { Carbohydrates (g) }\end{array}$ \\
\hline $\begin{array}{l}\text { Valores de referência } \\
\text { calculados/ Calculated } \\
\text { Reference Values }\end{array}$ & 1959,00 & 98,00 & 65,00 & 244,00 \\
\hline $\begin{array}{l}\text { Valores obtidos dos } \\
\text { pratos confecionados/ } \\
\text { Obtained values from } \\
\text { prepared dishes }\end{array}$ & 87,93 & 53,51 & 150,74 \\
\hline
\end{tabular}


lipid and $75 \%$ carbohydrate could be met. By adopting Menu 3, 74\% of the daily requirements of energy, $90 \%$ protein, $82.32 \%$ lipids and $62 \%$ carbohydrates could be met. Cooked dishes feature food from all groups on the food wheel: cereals and byproducts and tubers, vegetables, fruit, dairy products, fish and eggs, legumes and fats and oil.

The project "Eat well, live healthy" intends to offer to special patients, including the oncological patient, three varied menus, balanced and nutritionally rich, to promote food intake and ensure an adequate nutritional intake. Food is one of the environmental factors that most affect the sate of health and is essential for growth, development and maintenance of human life ${ }^{2,4}$.

The complete menus are prepared for all these special patients and aim to meet the nutritional needs that are, in general, increased in these patients. However, it should be noted that each patient's needs and specific features, and with the possible existence of other associated diseases, it would be necessary to individually monitor and create a specific food plan according to the needs of each patient ${ }^{4}$.

Proteins are responsible for the growth, maintenance and repairs of organs, tissues and cells of the body and also have an important role within the immune system. Protein deficits can be responsible for a longer recovery period and a lower resistance to infection. It is recommended that the protein provided is sufficient and meets the increased protein needs of cancer patients. Some recent studies suggest that adequate intake of protein is more closely related to positive results and better prognosis than total energy intake (specifically of macronutrients such as fats and carbohydrates) ${ }^{2,4,6}$. According to the guidelines of ESPEN, the recommended protein intake for cancer patients is 1.0 to $1.5 \mathrm{~g} / \mathrm{kg} /$ day, if possible ${ }^{4}$. The ASPEN guidelines make reference to a broader range of 1.2 to $2 \mathrm{~g} / \mathrm{kg} / \mathrm{day}^{6}$. For the preparation of the menus, the value of ingesting protein chosen was of $1.5 \mathrm{~g} / \mathrm{kg} /$ day. This choice is justified by the fact that the menus were to be consumed by any type of cancer patient, and to give a greater amount of protein could be harmful in the case of acute or chronic renal failure, for example, and also because it would be difficult to provide a high amount of protein solely through food without resorting to food supplements. To increase protein intake ensure good nutritional value and a) chose high-protein food (dairy products (milk, yogurt), eggs, fish (salmon, tuna, squid), legumes (beans, grain), vegetables and dried fruits (walnuts and peanuts); b) substitute water for milk in some preparations, namely in the preparation of walnut bread and the preparation of applesauce with peanuts; c) prepare meat broths (with chicken). It is not recommended to ção de hamburguér de salmão acompanhado por puré de ervilhas. A sobremesa do Menu 3 escolhida foi uma mouse de limão. Após realizados todos os cálculos relativos aos pratos confecionados verificou-se que através do Menu 1 poderiam ser satisfeitas as necessidades diárias de $71 \%$ de energia, $67 \%$ de proteínas, $81 \%$ de lípidos e de $60 \%$ de hidratos de carbono. Através do Menu 2 poderiam ser satisfeitas as necessidades diárias de $72 \%$ de energia, $98 \%$ de proteínas, $49 \%$ de lípidos e de $75 \%$ de hidratos de carbono. Pela adoção do Menu 3 poderiam ser satisfeitas as necessidades diárias de $74 \%$ de energia, $90 \%$ de proteína, $82,32 \%$ de lípidos e $62 \%$ de hidratos de carbono. Os pratos confecionados apresentam alimentos de todos os grupos da roda dos alimentos: cereais e derivados, tubérculos, hortícolas, fruta, lacticínios, carnes pescados e ovos, leguminosas e gorduras e óleos.

Com o projeto "Comer bem, Viver com saúde" disponibiliza-se ao doente em condições especiais, incluindo o doente oncológico, três menus variados, equilibrados e ri$\cos$ do ponto de vista nutricional, que promovam a ingestão alimentar e garantam um adequado aporte nutricional. A alimentação é um dos fatores ambientais que mais afeta o estado de saúde e é essencial para o crescimento, desenvolvimento e manutenção da vida humana ${ }^{2,4}$.

Os menus elaborados são direcionados para estes doentes e, pretendendo ir ao encontro das necessidades nutricionais que se encontram aumentadas, de uma forma geral, nestes doentes. No entanto, é de salientar que cada doente tem necessidades e características específicas e que pela possível existência de outras patologias associadas seria necessário fazer um acompanhemnto individual e a elaboração de um plano alimentar específico de acordo com as necessidades específicas de cada um ${ }^{4}$. As proteínas são responsáveis pelo crescimento, conservação e reparação dos orgãos, tecidos e células do organismo. Assumem também um papel importante ao nível do sistema imunitário. Défices proteicos podem ser responsáveis por um período de recuperação mais prolongado e uma menor resistência à infecção. Recomenda-se que a proteína fornecida seja suficiente e vá ao encontro das necessidades proteicas aumentadas dos doentes oncológicos. Alguns estudos recentes sugerem que a ingestão adequada de proteína está mais estreitamente relacionada com a obtenção de resultados positivos e melhor prognóstico do que a ingestão de energia total (especificamente de macronutrientes como a gordura e os hidratos de carbono) ${ }^{2,4,6}$. De acordo com as guidelines da ESPEN a ingestão de proteína recomendada para doentes oncológicos é de 1,0 a 1,5 $\mathrm{g} / \mathrm{kg} / \mathrm{dia}$, se possível ${ }^{4}$. As guidelines da ASPEN fazem referência a um intervalo mais alargado que vai de 1,2 a $2 \mathrm{~g} / \mathrm{kg} / \mathrm{dia}^{6}$. Para a elaboração dos menus, o valor de 
use food diets that restrict energy intake in patients with or at risk of malnutrition. In addition, in cases of weight loss of cancer patients with insulin resistance, it is recommended to increase the good fat/carbs ratio. In case of insulin resistance and oxidation of glucose uptake by muscle cells is impaired, however, the use of fat is normal or increased, by what can be beneficial a higher proportion of fat versus carbs ${ }^{4}$. It was decided to increase the percentage of fat in menus according to the indications of ESPEN ${ }^{4}$. It is recommended that the total energy expenditure of cancer patients, if not measured individually, be considered similar to healthy individuals and generally ranging from 25 to $30 \mathrm{kcal} / \mathrm{kg} /$ day. For the preparation of the menus the reference value was of $30 \mathrm{kcal} / \mathrm{kg} / \mathrm{day}^{4,6}$. In addition to increasing protein intake and energy density of meals, this project also aims to contribute to increase the intake of foods with high fiber content and to increase appetite. In order to increase fiber intake, rye and whole wheat flours were used, as was bread and toasts composed solely of whole wheat flour. The increase in fiber may be significant in reducing the effects and consequences to the gastrointestinal level in these patients. The use of salmon (in skewers or burgers), rich in Omega-3 fatty acids, is intended not only to increase the intake of protein, but also to increase the appetite. It has been suggested that the consumption of Omega 3 fatty acids can stabilize or increase appetite, lean body mass and body weight in advanced cancer patients undergoing chemotherapy and at risk of weight loss or malnutrition ${ }^{4}$.

\section{Conclusions}

Creating strategies in order to change the consistency of meals, the density, texture and improve the attractiveness of the dish can lead to improvements. The availability of menus will allow patients to be aware of the benefits from knowing their energy and protein needs and, potentially, to contribute to reduce and soften the side effects resulting from cancer treatment and allow a better recovery, a reduction of hospitalization time, and a better quality of life.

\section{Conflict of interest}

The authors declare that there is no financial or personal relationship that can be understood as representing a potential conflict of interest. proteína a ingerir escolhido foi de $1,5 \mathrm{~g} / \mathrm{kg} / \mathrm{dia}$. Esta escolha justifica-se pelo facto de os menus serem direcionados para qualquer tipo de doente oncológico e dar uma maior quantidade de proteína poderia ser prejudicial no caso de insuficiência renal aguda ou crónica, por exemplo e também porque seria díficil fornecer uma elevada quantidade de proteína unicamente através de alimentos sem recorrer a suplementos alimentares. Para se aumentar a ingestão proteica: a) escolheram-se alimentos com elevado teor proteico (lacticínios (leite, iogurte), ovos, peixe (salmão, atum, lula), carne (frango), leguminosas (feijão, grão), legumes e frutos secos (nozes e amendoins); b) substitui-se água por leite em algumas preparações, nomeadamente na confeção do pão de nozes e na confeção da compota de maçã com amendoins; c) fizeram-se caldos de carne (com carne de frango). É recomendado não usar dietas alimentares que restrinjam a ingestão de energia em pacientes com ou em risco de desnutrição. Além disso, na perda de peso de pacientes oncológicos com resistência à insulina recomenda-se que se aumente a razão gordura/hidratos de carbono. Em situações de resistência à insulina a absorção e oxidação de glicose pelas células musculares é prejudicada, no entanto, a utilização de gordura é normal ou aumentada, pelo que pode ser benéfico uma maior proporção de gordura versus hidratos de carbo$\mathrm{no}^{4}$. Optou-se por aumentar nos menus a percentagem de gordura fornecida ao doente oncológico, atendendo às indicações da ESPEN ${ }^{4}$. Recomenda-se que o dispêndio energético total de pacientes oncológicos, se não medido individualmente, seja considerado semelhante a indivíduos saudáveis e geralmente variando entre 25 a $30 \mathrm{Kcal} / \mathrm{Kg} /$ dia . Para a elaboração dos menus o valor de referência foi de $30 \mathrm{Kcal} / \mathrm{Kg} / \mathrm{dia}^{4,6}$. Além de aumentar a ingestão proteica e a densidade energética das refeições, este projeto também pretende contribuir, para aumentar a ingestão de alimentos com elevado teor em fibra e para aumentar o apetite. Com o intuito de aumentar a ingestão de fibra recorreu-se à utilização de pão de centeio e farinha de trigo integral e à utilização de pão e tostas unicamente compostos por farinha de trigo integral. $\mathrm{O}$ aumento de fibra pode ser marcante na redução dos efeitos e consequências ao nível gastrointestinal nestes doentes. A utilização de salmão (nas espetadas e no hambúrguer), rico em ácidos gordos ómega-3, pretendeu não só aumentar a ingestão de proteína, como também aumentar o apetite. Sugere-se que o consumo de ácidos gordos ómega 3 em doentes com cancro avançado e submetidos a quimioterapia e risco de perda de peso ou desnutrição, pode estabilizar ou aumentar o apetite, a massa magra e o peso corporal ${ }^{4}$. 


\section{Conclusões}

Criar estratégias no sentido de alterar a consistência das refeições, a densidade, a textura e melhorar a atratividade do prato podem acarretar melhorias. A disponibilização dos menus vai permitir que os doentes se consciencializem de que uma ajustada alimentação lhes permite suprimir as necessidades energéticas e proteicas e, eventualmente, contribuir para reduzir e suavizar os efeitos colaterais resultantes do tratamento e permitir uma melhor recuperação, reduzir o tempo de hospitalização e uma melhor qualidade de vida.

\section{Conflito de interesses}

Os autores declaram não existirem quaisquer relações de natureza financeira ou pessoal que possam ser entendidas ou representarem um potencial conflito de interesses.

\section{References/ Referências}

1. Direção Geral de Saúde. (2015). Portugal: Doenças Oncológicas em Números - 2015. Programa Nacional para as Doenças Oncológicas, 7-10.

2. American Cancer Society. (2015). Nutrition for the Person With Cancer During Treatment: A Guide for Patients and Families, 1-8.

3. Zhang, L., Lu,Y., Fang, Y. (2014). Nutritional status and related factors of patients with advanced gastrointestinal cancer. British Journal of Nutrition, 1239-1240.

4. Arends, J.,Bachmann, P., Baracos, V., et al. (2016). ESPEN guidelines on nutrition in cancer patients. Elsevier, 1-38.

5. Vashi, P., Dahlk, S., Popiel, B., et al. (2014). A longitudinal study investigation quality of life and nutritional outcomes in advanced cancer patients receiving home parental nutrition. BMC Cancer, 1-8.

6. Stephen, A., McClave, M., Beth, E. et al. (2016). Guidelines for the Provision and Assessment of Nutrition Support Therapy in the Adult Critically Ill Patient: Society of Critical Care Medicine (SCCM) and American Society for Parenteral and Enteral Nutrition (A.S.P.E.N.). Journal of Parenteral and Enteral Nutrition, 159- 211

7. Porto, A., Oliveira, L. (2010). Tabela da Composição de Alimentos. Instituto Nacional de Saúde Doutor Ricardo Jorge, $22-123$. 